\title{
Roles, Contributions and Dangers of Technologicaldevelopment in Nigeria
}

\author{
${ }^{1}$ Engr. Sangotola T.M, ${ }^{2}$ Olatinwo I.O, ${ }^{3}$ Ladipo O.A, ${ }^{4}$ Babarinde O.O. \\ Department of Civil, Mechanical, and Electrical Engineering \\ The Polytechnic, Ibadan, Adeseun Ogundoyin Campus, Eruwa
}

\begin{abstract}
This paper is to examine and proffer the solution that could be adopted to avert most of the persistent dangers of our technological development in Nigeria. It includes sustenance manpower development, government policy, lack of functional equipment, inadequate funding and poor societal attitude as some of the dangers; this paper will attempt to make analysis of respective issues, such as integrating of indigenous technology in our school programmes, upgrade of technology education, motivation towards professional training curriculum planner, evolution method and award for technological innovation.
\end{abstract}

Keywords: Manpower, Dangers of Technological Development, Government Policy, Contribution.

\section{Introduction}

Various authorities have differently defined the term technology. The Oxford Advanced Learner's Dictionary defines technology as the scientific study and use of mechanical arts and applied sciences. e.g. engineering and its application of the practical tasks in industry sees it as a systematic application of manufacturing methods and industrial arts to enhance efficiency in human activities; Furthermore, technology can simply be described as the result of man's efforts to do things more efficiently and effectively. Drucker (2007) defines technology as way or means of accomplishing a task.

\section{State of Technology in Nigeria}

From the Beginning of time, man has strived to improve his way and quality of life. The caveman discovered how to make and use tools, developed a logical sequence for activities, and evolved processes that added value to his life. The totality of the use and application of his knowledge, skills, tools, and materials constitutes what we today describe as "technology". If natural instinct directs us and compels the application of technology for the well-being of man, why is it that all human being has not exploited this in equal capacity?

Technology plays a fundamental role in wealth creation, improvement of the quality of life, real economic growth and transformation in any society. For example, the United States emerged from an agrarian economy into an industrial superpower in the $20^{\text {th }}$ century. Taiwan and Korea became industrialized countries by exploiting advances in silicon microelectronics from the early 1960s.

All of these countries invested quite heavily in people and factories, and their successes were based on carefully designed plans and strategies. Unfortunately, in many, if not all, of the non -developed (or "yet to develop") countries, technology is viewed as a consumable item, not something that can be produced or created. Technology is the primary engine of economic growth and provides the key to unlocking any country's potential. Hence, countries that want to develop must invest significantly in science and technology. This is achieved by developing the talent, the human capacity required to compete in a globally competitive world. A county is said to be technologically backward when:

(i) It cannot produce capital goods such as tractors, lathe machines, drilling machine, cars, trains, and other earth moving equipments.

(ii) It is unable to exploit her natural resources except with the help of Foreigners who will normally provide the technology and expertise to undertake the exploitation of her natural resources.

(iii) It is unable to mechanize her agriculture i.e. crude implements are used for agricultural production activities by a large percentage of those who are involved in agricultural production.

(iv) It depends on other countries for the supply of its spare parts for industrial machinery.

(v) It exports raw materials to other countries as against finished products.

(vi) It is unable to produce her own military hardware with which to defend herself if the need arises.

A critical examination of Nigeria reveals that all the points itemized above are present in the country. Thus Nigeria as spelt out in the items above is a technological backward country. 


\section{Historical Background of Technological/Industrial Development in Nigeria}

The concept of technological development in Nigeria evolved through the years after political independence in 1960; there was the concern for economic independence. The aim was that Nigeria should gradually reduce her dependence on Britain her former colonial master that dominated the production and distribution organization in Nigeria at that time. Economic development was to progress in an orderly manner and no dislocation to the system was to be allowed. The existing companies were to be encouraged and new ones were to be attracted to increase investment in Nigeria.

The thinking of Nigeria business policy makers up to the end of the civil war in 1970 was that Nigeria had a lot of resources (land and manpower) but lacked the capital to effectively develop them. Foreign investments were therefore to be vigorously encouraged. Nigeria was to be non-aligned so as to attract capital from both East and West. This, it was thought, would gradually reduce the grip Britain had on Nigeria's economy.

The Nigerian Enterprises Promotion (Indigenization) decrees of 1972 and 1977 forced the foreign firms operating in Nigeria to sell a sizeable portion of their ownership stocks to Nigerians. After the Nigerian civil war in 1970, capital for the government was given a big boost by favourable developments in the oil industry. The volume of oil produced in the country increased tremendously, with the development of oil fields in the Western Region (Delta State) of Nigeria. The Arab/ Israel war of 1973 resulted in the Arab oil embargo on the West This action shot the price of oil to $\$ 42.00$ per barrel with consequent increase in revenue to Nigeria. For what the lay men can see, a lot of this revenue was used to build bridges, construct highways, build vehicle assembly plants, steel plants, Aluminium smelter plants, the Kanji dam and other power generating stations, Universities, Polytechnics, etc. Our fraudulent and visionless leaders also lavished a sizeable part of this revenue on the then notorious "Festac 77", and the remaining stashed away in foreign banks in Switzerland and other countries. Today, even with our democratic dispensation, the status quo has not changed.

\section{The Need for Technology Development in Nigeria}

Since we all know the importance of technology we should make wide spread of it in our country so that we can have a solid background in academic. Technology helps in building a nation effectively and efficiently. We should not forget that technology helps in opening business relationship with other friendly Nations. And also help the educational programmes of our country more productive and effective.

These are the importance of technological development of educational sectors:

i. Technology makes learning interesting.

ii. Technology makes learning process more suitable and effective.

iii. It fast in achieving educational pursuit in academic background.

iv. Technological equipment stimulates interest and assimilation in teaching process.

v. Technology is used for development and improvement on the educational curriculum in educational system.

The federal government should be more concern to technological advancement to our country, Nigeria. They should bring new modern technological equipment for school and train qualified personnel who can make good use of it in impacting or using it to teach effectively and efficiently. Because new technological equipment has opened up new opportunities for developing countries like Nigeria, which possess the required skills to provide expert-oriented service such as data entry, data processing and software development.

Achieving all these will provide job opportunities for many Nigerians for the economic and social development of our nation.

\section{Contributions of Technological Development in Nigeria}

Science and Technology (S \& T) effort is usually measured by indicators of science and technology, human resource development, research and development, institutional infrastructure and private sector investment in science and technology activities. The specific indicators normally include science enrolment in secondary, technical, vocational and tertiary institutions; national spending on science and technology education, research and development spending by government and private sector and tertiary institutions; number and research and development coverage of institutions among other indicators.

As at 1995, about total of 602 Research and Development centers in Africa, of which 232 were engage in research pertaining to Agriculture, Forestry and Fisheries. Another 50 were in Health and Nutrition fields, while only 50 were involve with manufacturing research. Africa has 90 Institutions doing social human sciences research, while another 57 were multi-disciplinary in their focus. The predominance of Agriculture Research Institutions is reflected in the significant contribution of $\mathrm{S} \& \mathrm{~T}$ in the Agricultural Sector of many of the countries.

Trained workers earn reasonable income and are accorded recognition cum respect by the community. By training individual, employments through technology not only provide them with a source of income but 
also provide them with social contract and reasonable participation in an organization. Also, it increases employ ability and job mobility of individual. An individual who is well equipped with saleable skills is versatile. As a result of the versatility, new modern technology will be able to utilized and better fit into the modern society dominated by the product of technology.

\section{Causes of Technological Backwardness in Nigeria}

The reasons why Nigeria is technologically backward today are many and varied. They include the following:

(a) Discouragement of Technological Growth by our Colonial Masters: There are many reasons why the British came to Nigeria. One of the reasons is economic (Boahen 1966). The British saw Nigeria as a ready market for their sprits, dane guns, mirrors and other goods. Before the advent of colonialism Nigerians were involved in many aspects of industrial and practical arts. They made their own hoes and other implements for farming, were able to weave their own clothes, smelted bronze and were able to cast an object as intricate as the "Festac mask" that was stolen by the British, undertook tanning of hides and skin amongst others. According to Akaninwor (2008), the colonialists discouraged further development of Nigerian technology as they reasoned it was a threat to the smooth marketing of goods imported from Europe. He went further to assert that "ogogoro" was termed illicit gin by the colonialists, and whoever was caught producing, marketing, or consuming it was persecuted.

(b) Colonial Education: Formal education is the main and proper channel for technological emancipation provided it is built on appropriate philosophy of education. The philosophy of Nigerian education during the colonial period was built on the wrong philosophy as can be confirmed by the statements of Lord Lugard and Rev. J.C. Taylor who said respectively:

"The chief function of government primary and secondary schools among primitive communities is to train the more promising boys from the village schools as teachers for those schools, as clerks for the local native courts, and as interpreters: (Lord Lugard 1921)'”.

"I looked upon them as the commencement of our missionary work. We lost no time and began to teach them the A.B.C." (Taylor 1857). It is therefore not surprising that apart from the Yaba Higher College that was established in

1947 to produce middle level technical manpower, the colonialist only established secondary schools that were meant to produce clerks, missionaries, and interpreters. The aspect of education which emphasize skill and practical competence was however not an integral part of our colonial educational system as at that time.

(c) Industrial Policies after Independence: The major industrial policy that Nigeria embarked upon after independence was import substitution industrial policy. The major thrust of this policy was:

(i) Building of assembly plants in Nigeria.

(ii) Importation of completely knocked down(CKD) parts into Nigeria to be assembled in these plants.

(iii) The establishment of steel plants, like Delta Steel Plant and Ajaokuta Steel Plant, and associated foundries that were to produce automobile parts that would be assembled in already established assembly plants.

(iv) The establishment of machine tool companies (like Oshogbo Machine Tool Company) that were supposed to produce capital goods.

The import substitution industrial strategy did not go beyond the stage of building the assembly plants, as the technical partners know that if Nigeria stops importing CKD parts, their companies in Europe would automatically stop production and eventually fold up. It meant that Nigeria would no longer be a market for European cars.

(d) Inability to Commercialize Research Findings: There are a good number of research institutions in Nigeria. Some of these are Product Development Agency, (PRODA) Enugu, Federal Institute of Industrial Research, (FIIRO) Oshodi, Nigerian Institute for oil Palm Research, (NIFOR) Benin City, Rubber Research Institute of Nigeria, (RRIN) Benin-City amongst others. These institutions have made a good number of findings or inventions but the lackadaisical private sector has not thought it fit to commercialize these inventions. Our universities and polytechnics have also invented different equipment, which nobody has bothered to commercialize for effective productivity. Today these Research institutions are a mere shadow of themselves, as the Nigeria factor has not helped them develop further.

(e) Refusal to Develop Military Invention made by Biafra during the Civil War: It is generally believed that necessity is the mother of invention. Under the fire power of the military government during the civil war,(19661970) Biafra produced a lot of fighting machines equipment, bombs and other sophisticated items using local technology trample the "Red Devil" armored personnel carriers, Ogbunigwe (mass killer), orange peel mosquito coil bombs etc. (The African Guardian July 23 1997). The Biafrans even extracted and refined their own petroleum product. But because of pride and incept leadership Nigeria has not made a positive effort to cash on 
this war time inventions, sit down and find out how these skills can be further improved upon to enhanced productivity because of the greediness that has blind folded our visionless leaders

(f) Government Attitude: Government attitude towards breaking the jinx of technological backwardness in Nigeria is both disgusting and appalling. Nigeria is probably the only country in the world where you can find all brands of cars without any one having been designed and made by Nigerians. Policy makers take technological decisions without consulting Nigerian engineers and technologists. And where sometimes good policies are taken, the follow up and implementation becomes an uphill problem as out implementation methodology in all facets of our Nation has never been adequately sustained.

(g) Poorly Equipped Educational Institutions: Our universities, polytechnics and technical colleges that are supposed to train proficient engineers, technologists, and technicians are now filled with obsolete and in most cases non-functional equipment. This affects the quality of products from these technological institutions. India, it is claimed, ranks third to the United States and the former USSR in scientific and technical manpower (The Nigerian Engineer, December 2003). It has over four million scientists and engineers. In 1985, Indian universities have 750,000 Engineering students registered. There are five elite institutions called India Institutes of Technology, funded and equipped to the highest standards, to provide high quality university graduates in electronics, computer science and other high technology disciplines. Their products emigrate in large number to the United States and other countries to apply their high skills where they are also valued and in demand, like the Republic of Ireland and Philippines It is however not a surprise to see engineering graduates in our Nigerian Universities who cannot differential between a bolt from a nut.

\section{Conclusion}

We must appreciate the fact that no situation is totally hopeless. Nigeria, as a nation, can leave the group of technologically backward nations to one of the most technologically advanced nations if the following suggestions are implemented.

(a) Copying items already in the Market: This method requires that laboratories, workshops, and other facilities be developed for component analysis and for building prototypes of items to be produced. The idea is to knock down products of interest in the workshops, study and analysis each component in the laboratories to ascertain chemical composition, physical properties and other production parameters of interest and replicate such items. Government should encourage "Igbo made" items and should assist in improving the quality of their products so as to compete favorably with the imported ones.

(b) Industrial Espionage: Highly technical and military technology is closely guarded by their proprietors. The secrets can be obtained either by direct investments or through espionage. Spies are often employed to collect top secrets and company documents required for developing such products, which they pass on to their sponsors for a fee.

(c) Provision of Infrastructural Facilities in our Schools: The ideals of the society are supposed to be passed to the next generation by the school system. Presently, the older universities in Nigeria have obsolete tools and the newer ones cannot afford to equip their laboratories and workshops. Otubanso (2005) in "Education for Underdevelopment" quoted a chemistry professor as saying that "students no longer do practical but only the theory of practical." If our students cannot do basic practical how can we aspire to a technological breakthrough? It is therefore imperative that for us to overcome the problem of technological backwardness, we (the public and private sectors) must invest monumental resources towards upgrading our educational infrastructures. We should probably recall the statement of Martin Luther King, who said: "The prosperity of a country depends not on the abundance of its revenues, nor on the strength of its fortifications, not on the beauty of its public buildings, but it consist in the number of its cultivated citizens, its men of education and enlightenment of character."

(d) Adequate Financing of Research Institutions: A good number of research institutions in Nigeria are not adequately funded. This continues to militate against effective research undertaking. India for example invested over three billion dollars in 1985 in some 1,300 research institutes working on electronics aeronautics and space, atomic energy, etc In 1985, India spent $1.5 \%$ of her GNP on research and development compared with about $2.5 \%$ spent by the US. Nigeria's highest allocation figure was $0.43 \%$ in 1983 , which went down to $0.05 \%$ in 1992 and $0.23 \%$ in 2003 (The Nigerian Engineer, Vol. 35 No. 4 December 2003): This is very sad for a sector whose responsibility is to research into areas that will enhance development in the country. 


\section{REFERENCES}

[1]. Drucker B. (2007), Technological Development for Human Sustenance. Pg. 4-5.

[2]. Emmanuel O. E. (2007), The Role of Technology in National development. Pg. 14-16.

[3]. Ezeji K.O. (1990), Mechanism for Enhancing Technological Education in Africa. Pg. 4-6.

[4]. Homby A.S. (2000), Oxford Advance Learner Dictionary of Current English: London.

[5]. Johnson P. (1987), The Shinto Civilization: London.

[6]. Otunbanso V. (2005), Education for Underdevelopment. Pg. 5-7.

[7]. The Nigerian Engineer, (2003), Vol. 35 No. 4 December.

[8]. Ulinfun B. (1992), Problems of Technological Education. Pg. 8-10. 